Article

\title{
Bilal Philips as a Proponent of Neo-Traditional Salafism and His Significance for Understanding Salafism in the West
}

\author{
Adis Duderija ${ }^{1, *}$ and Ghulam Rasool ${ }^{2}$ \\ 1 School of Humanities, Griffith University, Queensland, QLD 4122, Australia \\ 2 Centre for Culture, Media and Governance, Jamia Milia Islamia, New Delhi, Delhi 110025, India; \\ grd@gmail.com \\ * Correspondence: a.duderija@griffith.edu.au
}

Received: 17 May 2019; Accepted: 4 June 2019; Published: 5 June 2019

\begin{abstract}
This article aims to explain the ideas and the significance of Dr. Bilal Philips, a prominent 'Salafi'preacher, a major proponent of Neo-Traditional Salafism, and how his writings and activities can aid us in understanding the dynamics regarding the nature of Salafism in the West as a discursive tradition with deep roots in the Islamic intellectual history, as well as an element of global Salafi movements. As such, the article focuses primarily on identifying and analyzing Philips' ideas on what constitutes a proper approach to interpreting the Qur'ān and Sunna in the light of the Islamic legal and exegetical tradition. After discussing the reasons why the ideas of Philips are significant for understanding Salafism in the West, the article focuses on his views on the conceptual relationship between sunna and hadith, the broader hermeneutic characterization of the main four Sunni schools of thought (madhāhib), and issues pertaining to the correct methodology of Qur'ānic exegesis (tafsìr). The article also discusses the internal factionalism and the contentedness of the category of Salafism among western Salafis by examining one critique levelled at Philips by his fellow Salafis residing in the West, with the view of not only understanding and situating the views of Philips more accurately but also to provide an avenue to understand the internal Salafi dynamics in the West in particular.
\end{abstract}

Keywords: Salafism; Salafism in the West; neo-ahl al hadith; ahl al hadith; Bilal Philips; tafsir; sunna; hadith; Neo-Traditional Salafism

\section{Introduction}

Bilal Philips (b. 1947) is a Canadian citizen of Jamaican ancestry. He adopted the Islamic faith in 1972. Since his conversion, he has spent most of his time in the parts of the Muslim world that have a strong Salafi presence, such as Saudi Arabia, the UAE, and Qatar (Roald 2012, pp. 351-52). Currently, he resides in Qatar, from where he is directing and overseeing the activities of the Islamic Online University that he founded in 2007. He is its current Dean. ${ }^{1}$ Apart from his Ph.D. in Islamic theology with the focus on exorcism in Islam that he completed in the early 1990s at the University of Wales ${ }^{2}$, all of his other educational qualifications were obtained from the main Saudi Arabian Islamic Universities. More specifically, his B.A. in Islamic Studies was completed at the University of Madinah in 1979, and his M.A in Islamic Theology was completed at King Saud University in Riyadh in $1985 .{ }^{3}$

\footnotetext{
https://islamiconlineuniversity.com/islamic-studies-faculties/.

http://tsd-l.worldcat.org/title/exorcism-in-islam/oclc/669684809\&referer=brief_results.

http://www.newmuslim.net/quran-sunnah/hadith-the-second-fundamental-source-of-guidance/.
} 
Philips was one of a number of African American Muslims who, in the early 1970s, were successful in obtaining scholarships to study various Islamic sciences in Islamic institutions in Madina and Mecca with the view of aggressively spreading the 'Salafi' approach to Islam upon their return to their home countries (Diamant 2016, pp. 206-7, 216, 237). In fact, Philips was part of "a group of the key foundational figures of the movement" and, in fact, was "the first Westerner to enroll at the University of Medina" (Meleagrou-Hitchens 2018, p. 46). After graduation, these individuals would maintain strong links with their teachers from Saudi Arabia and would regularly consult them on various Islamic issues (Diamant 2016, pp. 206-7).

The African American Salafi movement emerged strongly in the 1990s and was, in many ways, a by-product of the efforts of the individuals like Philips and the regular networks and relationships they established and maintained with the major religious authorities in Saudi Arabia like Bin Baz (d. 1999) and al-Uthaymin (d. 2001) (Ibid.). This indelible Saudi Arabian influence on the African American Salafis and their emergence is aptly noted by Diamant as follows:

African American Salafi movement existence was inextricably linked to Saudi proselytization efforts. Crucially, the Salafi mosques would nurture relationships with elderly shaykhs in Saudi Arabia whose words from Medina would directly affect communal disputes that arose among African American Salafis. Fatwas and other statements made by these shaykhs were issued six thousand miles away. (Ibid., p. 206)

As alluded to above, Philips, however, has been residing primarily in various Gulf countries either teaching Islamic Studies/Arabic and/or setting up various Islamic educational and charity organizations globally. ${ }^{4}$

\section{Significance of Bilal Philips for Understanding Salafism in the West}

Though Philips continues to reside in the Muslim majority world and has been banned from entering countries such as the UK, Denmark, Australia, and Germany from about the middle of 2000s onward, there are a number of reasons why his ideas and activism are important in understanding Salafism in the West. One of these is his formidable output in form of books, booklets, and audiovisual material, most of which were written in the 1980s and 1990s and, therefore, long before he was banned from the above countries. ${ }^{5}$ Moreover, many of Philips' books and booklets primarily published by Saudi Arabian publishing houses, such as Dar as Salam and International Islamic Publishing House in Riyadh ${ }^{6}$, continue to be available freely as pdfs online (also available are dozens of lectures and YouTube videos). These books have been able to attract wide appeal among Muslims in general—not just those of Salafi inclination (Hamid 2016).

Furthermore, the topics of these books (and the audiovisual material) are wide ranging and discuss significant contemporary issues as well as those from the premodern Islamic interpretive tradition. Just as importantly, the themes Philips discusses in his work, both premodern and modern, touch on issues that are of great relevance to the contemporary Muslims in the West, especially the younger demographic that is often disconnected from the Islamic religio-cultural heritage but is in search of "Islamic" answers (Duderija and Rane 2019). One reason why Philips' writings are topical is because they address the major moral challenges/dilemmas facing western Muslims, such as the concept of the "West,' issues pertaining to marriage, abortion, the relationship between Islam and science, and the relationship between Islam and terrorism. ${ }^{7}$ Furthermore, the writings of Philips are relevant to western

http://bilalphilips.com/about/.

Most of which is catalogued on his website: http://bilalphilips.com/about/.

https://iiph.com/about-iiph-store/about-iiph.html.

See, especially, The Clash of Civilisations; An Islamic Point of View, https://archive.org/details/TheClashOfCivilizationsanIslamicView.pdf/page/n7; The Moral Foundation of Islamic Culture https://contentislam101.files.wordpress.com/2015/04/ the-moral-foundations-of-islamic-culture-by-bilal-philips.pdf; Contemporary Issues, https://d1.islamhouse.com/data/en/ih_ books/single/en_Contemporary_Issues.pdf. 
Muslims because they discuss controversial and still contested/unresolved issues pertaining to the various aspects of the premodern Islamic intellectual history, such as the nature of what constitutes the correct (prophetic) methodology of interpretation (manhaj) of the foundational sources of the Islamic worldview; questions pertaining to the correct Islamic belief and creed (tawhìd and 'aqìda); the concept of innovation in Islam (bida'); the concept of taqli d and ijtihād; the methodological differences in Islamic schools of thought (madhāhib) and how they arose; issues concerning Sunni-Shi'i polemics; Qur'anic exegesis; and the status of hadith and sunna as sources of Islamic legal authority.

Another reason why the ideas of Philips are important in understanding Salafism in the West is that his writings assume little or no prior knowledge of Islam and are written in accessible language; thus, they are perfectly suited to those Muslims in the West who have had little exposure to their faith's intellectual tradition. In this respect, it is important to highlight that most of Philips' writings have been written for western, English-speaking, and Muslim audiences in mind. We will examine a number of these in some detail in the next section where we discuss why Philips should be considered a proponent of what elsewhere has been termed Neo-Traditional Salafism (Duderija 2011). His influence, however, goes well beyond English-speaking, western, and Muslim culture, as several his book/booklets have been translated into a number of European languages, such as German, ${ }^{8}$ French, ${ }^{9}$ and Spanish. ${ }^{10}$

An additional significant reason why the ideas of Philips should command our attention from the perspective of understanding Salafism in the West is his considerable online presence. Philips is very active on major social media platforms such as Facebook and Twitter. He tweets several times a day and has over 670,000 followers on Twitter. ${ }^{11}$ Moreover, he has over 6 million followers on Facebook, and, here, he also makes several posts a day regularly. ${ }^{12}$ It is also noteworthy that Philips' YouTube channel has over 40,000 subscribers. ${ }^{13}$ He also has a considerable presence on global satellite channels like Peace TV, ${ }^{14}$ Huda TV, ${ }^{15}$ and Islam Channel. ${ }^{16}$

There are additional concerns we should consider when assessing the significance of Phillip's approach to Islam and its effects on Salafism in the West. As mentioned above, Philips is the founder and dean of the Islamic Online University (IOU). Based on the figures presented on its website since its establishment in 2007, it has attracted 270,000 registered students from 228 countries. ${ }^{17}$ Furthermore, we are told that over 46,000 live classes have been held over the internet in the period of 2010-April $2016 .{ }^{18}$ It is also worth noting that, for a number of years now, Philips has also been included in the 500 most influential Muslims list. ${ }^{19}$ Finally, Bilal Philips is representative of a more intellectual form of Salafism in the West that has additional appeals that are specific to Muslims in the West, as they concern issues pertaining to their cultural and ethnic identities and how they interrelate with their religious one, as well as influencing western Muslim views on what constitutes an ideal/original//normative/pure form of Islam. Hamid, in the context of writing on the Salafi movement in the UK, emphasizes these aspects of appeal of Salafism for the Muslims in the West as follows:

http://www.imm-aachen.de/E_Books/Tauhid.pdf.

https://www.amazon.com/Fondements-Tawhid-Monotheisme-Islamique/dp/6035010628.

10 https://d1.islamhouse.com/data/es/ih_books/single/es_Evolucion_de_la_jurisprudencia_islamica.pdf.

https://twitter.com/DrBilalPhilips?ref_src=twsrc\%5Egoogle\%7Ctwcamp \%5Eserp\%7Ctwgr\%5Eauthor.

https://www.facebook.com/DrBilalPhilips/.

https://www.youtube.com/channel/UCk1-R7Mmzd7iikof378dcuA.

14 Headquarters in the UAE. Founded by a popular Salafi Indian preacher Zakir Naik. www.peacetv.tv. This stating broadcasts in English and Urdu.

15 A satellite TV channel in Saudi Arabia. www.hudatv.tv. Broadcasts in English.

16 A free to air and broadcast in English. Based in the UK. http://www.islamchannel.tv/.

17 As per this link from 2019, the number now is 450,000. https://www.themuslim500.com/profiles/dr-abu-ameenah-bilalphilips/.

18 https://islamiconlineuniversity.com/history/.

19 https://www.themuslim500.com/profiles/dr-abu-ameenah-bilal-philips/. According to this link from 2019, the total number of students that have registered at IUO is 450,000 . 
People found in Salafi perspectives an approach to religious commitment that seemed to be intellectually rigorous, evidence-based, and free of the corruption of folkloric religion or the 'wishy washy' alternatives offered by $\mathrm{YM}^{20}$ or the hyper-politicization of $\mathrm{HT}^{21}$. Compared to YM and HT, Salafis seemed to be taking their religion more seriously. The Salafi trend mainly attracted young second-generation male and female South Asian Muslims in addition to a significant number of black and white converts. Well-known preacher Abdurraheem Green epitomizes the appeal by saying, 'Salafi thinking was powerful because it exposed the discrepancies between religion and culture,' while Abdul Haqq Baker insists that Salafism represents 'simplicity, clarity, connectivity, and a chain of authenticity to early orthodoxy - that is to say, the Qur'ân and Hadīth.' When younger Muslims and converts become convinced, adopting a Salafi identity becomes a straightforward process of exchanging and rerouting religious symbols and acquiring membership of a de-ethnicized supranational identity. (Hamid 2016, p. 59)

Hamid similarly states:

Salafis gained influence within British Muslim communities by claiming to return to the primary texts of Islam and rejected what they considered alien religious beliefs and practices. Embracing Salafi identities was ultimately an attempt by Muslim young people to learn and practice their religion. Salafism provided certainty, clear group identity, and an individually empowering approach to the sources of the religion with a compelling evidence base. It allowed for an adoption of a 'rationalized Islam,' one which was 'stripped of the niceties and ambiguities of juristic reasoning, the complexities of theology and the subtleties of Sufism.'. (Ibid.)

Furthermore, Salafism is a major, global Islamic movement, and the global debates among various Salafi movements, including the jihadists, have a direct and significant impact on the Salafi community in the West (Meijer 2009). Moreover, the Salafi community in the West considers itself bound to defer to the scholarly authorities stemming from the epicenter of Salafi thought in the Middle East and is often primarily engaged in translation of the works of these scholars into European languages for the purposes of spreading their interpretation of Islam. A pertinent example of this is one of the major Salafi websites in the UK, Salafimanhaj.com, that translates the works of Salafi scholars such as S. Al-Fawzan (b. 1933) into English and makes them freely available on the website. ${ }^{22}$ In many ways, for reasons explained below, this deferral to the Salafi scholarly authority in the Middle East also applies to Bilal Philips.

Given the reasons outlined above as to why Philips' ideas should be considered as significant in understanding contemporary Salafism (in the West) or contemporary Islam and Muslims more generally, it is interesting that very little academic scholarship on Philips exists. The work of Roald (2012, pp. 351-52) devotes merely two paragraphs to Philips in the context of discussing several high-profile converts to Islam in the 20th and 21st century and the various conversion stages they underwent. Roald describes Philips approach to Islam as 'Wahhabi' and "Salafi,' noting that Philips himself does not use these terms ${ }^{23}$. She broadly situates his methodology/manhaj as a "literal" approach to the hadith "in the manner of prominent Salafist scholars" and his theological orientation "both in relation to the nature of God and the practice of Islamic rules and regulations" as "salafi" (Ibid., p. 351). Another scholar who briefly mentions Philips as a prominent proponent of Salafism is Mathias

\footnotetext{
Youth Movement UK.

Hizb ul tahrir (UK).

http://download.salafimanhaj.com/pdf/SalafiManhaj_CallTo_Allah.pdf.

This claim is, however, not true, as evident on his personal website, especially under the tab "Reply to Critics' where he clearly uses and identifies himself as a "salafi,' i.e., a follower of the main apolitical Saudi Salafi authorities. See our main discussion below, especially the final section.
} 
Rohe, who in the context of discussing main approaches among western Muslims in relation to the nature of and the debates over the Shari'a identifies Bilal Philips as "a proponent of imagined original pure Islam" that is "opposed to democracy and human rights, which are denounced to be a Western invention" based on the doctrines of Salafism (Rohe 2014, p. 271).

In what follows, we offer a more detailed description and delineation of Philips methodology of interpretation (manhaj) and situate it in relation to the Islamic intellectual tradition as it relates to the debates on the relative status and the authenticity of various sources of legal authority in the Sunni Islamic tradition. In this respect, we argue that Bilal Philips should be considered as a proponent of what Duderija (2011) has elsewhere termed Neo-Traditional Salafism or in the terminology of Wiktorowicz (2006) quietist Salafism. The article's strong focus on analyzing and situating Philip's manhaj is justified on two fronts. First, as noted above, Salafism in the West, as an intellectual/scholarly endeavor, is heavily embedded in scholarly discussions that have deep historical roots in the Islamic interpretive tradition, and these are explicitly discussed in the work of Philips. Second, again, for reasons discussed above, Salafism in the West is part of a global Salafi movement that is strongly affected by the scholarly discussions on what constitutes true Salafi manhaj that occur at the global level, and the manhaj-based ideas discussed by Philips are part of this discourse.

\section{Bilal Philips as Proponent of Neo-Traditional Salafism}

Duderija (2011) defines Neo-Traditional Salafism (NTS) as a contemporary movement that has its roots, in terms of its approach to the interpretation of Qur'ān, Sunna, and the Islamic intellectual tradition, in the premodern ahl al-hadith movement that emerged in the second century of the Islamic calendar (Melchert 1997). The main contemporary scholars associated with this approach globally are those of a long time Saudi Arabian mufti A. Bin Bazz (d. 1999), M. Al-Uthaymin (d. 2001), and the hadīth scholar N. Al-Albani (d. 1999) and their students (Duderija 2011, pp. 49-68).

Since the focus of our article on Philips is on identifying him as a prominent figure of NTS in terms of its manhaj, it is important to provide a brief overview of the main delineating features of the NTS manhaj. Duderija describes it in following terms:

i. The NTS school of thought in relation to how it conceptualises the concepts of 'ilm, Salafism, and sunna, its relative status in relation to the Qur'ān and hadith bodies of knowledge, and its relation to non-textual sources of knowledge such as 'aql, $r a^{\prime} y$, istishān, taqlïd, etc., should be considered as a contemporary incarnation of the pre-modern ahl al-hadith school of thought:

ii. The proponents of NTS advocate a completely textual legal hermeneutic expressed best in their definition of $i t t i b a$ ' as an unflinching adherence to what they consider to be 'sahì $h$ ' hadith, which, in turn, is conflated with following the true Salafi Qur'ān-Sunna manhaj.

iii. The NTS manhaj as identified and described by themselves is often non-specific and vague, consisting of amalgamations of Qur'ānic verse and what are considered to be "authentic" (sahì) hadīth and, at times, is accompanied by a short commentary of classical scholars who themselves espouse the ahl al-hadith manhaj.

iv. It shows no evidence of being consciously grounded in, or even aware of, any modern theories of interpretation/hermeneutics.

v. The NTS manhaj is often disclosed by means of what can be termed discourse of oppositional dialectics where the NTS manhaj is contrasted in general terms with 'new methodologies of modernist and intellectuals' or that of the madhähib or Sufis.

vi. One important part of the NTS manhaj is their subscription to a particular interpretation of the concept of al wala' 'wal barā', which is considered part of the 'aqì $d a$, which is very narrow and considers itself only as the Saved Sect (firqa nājiya) (Ibid., pp. 25-68).

Duderija has also delineated the assumptions underpinning its manhaj as follows:

i. A philologically-centered interpretational orientation; textual 'intentionalism,' i.e., the subscription to a voluntarist view of law, ethics, morality, and ontology; 
ii. the belief in the fixed, stable nature of the meaning of the Qur'anic text residing in totality in the mind of its Originator;

iii. the decontextualization and marginalization of Qur'ānic revelatory background for the purposes of its interpretation;

iv. the 'voluntarist-traditionalist' view of the relationship between reason and revelation;

v. textual segmentalism and the lack of a thematic and holistic approach to textual evidence (adilla)

vi. a heavily textualist approach to maquasid al shari'a

vii. a hadith-dependent concept of sunna that, conceptually, conflates the concept of an "authentic" (sahīh) single (ahad) hadīth with that of the concept of sunna (Ibid., pp. 69-84).

In the analysis that follows, it is important to keep in mind these overall NTS manhaj-based commitment as we evaluate the ideas of Philips. However, given the space constrains, it will not be possible to analyze and evaluate Philips views in relation to all of the aspects of the NTS manhaj outlined above. The focus will be primarily on identifying Philip's views on: (i) The conceptual relationship between hadīth and sunna; (ii) the concept of taqlìd/ittiba'/madhāhib; and (iii) what constitutes the correct Qur'ānic methodology of interpretation (tafsīr).

\section{Philips on the Conceptual Relationship between hadīth and sunna}

As outlined in the previous section, the NTS manhaj is characterized by certain conceptualizations of the role and the function of hadīth in interpretation of Qur'ān and Sunna, the role of sahìh ahad hadith as source of legal authority in the realms of figh and 'aqida, their understanding of the concept of taqli $d$ and its relationship with ittiba', or the unflinching adherence to hadith. In what follows, we offer evidence from the writings of Philips that he indeed follows the NTS manhaj on these issues. We will start with his view on the concept of Sunna and the role of hadith in relation to it.

To contextualize the views of Bilal Philips on the question of hadith and sunna, it is important to understand the significance of sunna and hadīth in Islamic ethics, law, and beliefs system ('aqìda). First, a brief discussion as to what constitutes an authentic hadith according to classical Islamic hadith sciences is in order. It is also essential to understand the concept of sunna itself and to what extent this concept is commeasurable with that of a sahih ahad hadith. The significance of this approach is to allow us to situate the thought of Philips as a proponent of the NTS sunna manhaj, which conflates the concept of sunna with that of sahih ahad hadith as defined by classical hadīth scholars, such as Ibn Salah (d.1245 CE). ${ }^{24}$ This approach to sunna was elsewhere termed "a hadīth-dependent concept of sunna," by which it is meant that that compliance (or otherwise) of certain (legal, ethical, or creedal) practices or principles with sunna is, and can only be, determined by means of sifting through numerous hadith reportedly going back to the time of the Prophet Muhammad via an authentic chain of narrators (isnād) (Duderija 2015, pp. 2-4).

A sound hadith, according to the those who specialize in hadith compilation and authentication—the muhaddith $\bar{u} n$ - consisted of a maț (text) and chain of transmitters (isnād), usually but not always going back to the Prophet. Muhaddithūn have formulated an impressively elaborate and complex hierarchy of hadīth authenticity that is primarily focused on examining the isnād and asking questions, such as how trustworthy, in terms of their character, are the people in the chain, when and where they lived, and how likely it was that they could have met each-other. These were categorized as sahīh (sound), hasan (good), daîf (weak), and other intermediate values (Kamali 2002; Brown 2009).

Another approach to authenticating the hadīth is by the Islamic legal theorists (usūliyyūn). They were primarily concerned with issues pertaining to the nature of knowledge, legal theory, and its methodology. The usūliyy $\bar{u} n$, therefore, had a different methodology when approaching the issue of

24 See our discussion in the main text below. 
hadith authenticity which centered around the question of what kind of knowledge the hadith yielded, (i.e., certain or uncertain). Put differently, their approach was epistemological in nature. As alluded to above the evaluation of the soundness of a hadīth, a task of the muhaddithün was primarily based upon the uprightness ('adāla) of the narrators founded on certain criteria, such as his/her memory and character, regardless of its epistemological value. The epistemological study of hadith concerned itself with the number of individual chains of narrations ranging from ahad (isolated) to mutawatir (successive). The mutawātir hadith were said to be those narrations which have been transmitted by such a large number of people that, according to great majority of usūliyyün, they yield certain or immediate (darurī) knowledge (Zysow 1984, pp. 11-31). It must be noted, however, that there is no consensus on either the criteria pertaining to assessment of uprightness of narrators (ilm-ul-rijal), or on how many isnād constitute and render a narration mutawātir. There are indeed very few mutawātir hadith, including those that (could) relate to law (Hallaq 1999, p. 79). Ahad hadith, on the other hand, are those narrations which do not fulfil the mutawātir criteria. Therefore, by default, they do not yield certain knowledge (yaqīn), as stipulated by the majority of Muslim usūliyyūn—only uncertain (zanni) knowledge (Zysow 1984). The ahad narrations form, by far, the largest bulk of the canonical hadith literature, and there are very few, if any, hadith that are not ahad (Hallaq 1999). Let us briefly point out that many influential muhaddithün-especially those associated with the heavily textualist and hadith-centred approaches to Islamic legal theory, such as the most senior NTS authority on hadith, Al-Albani, one of Philip's teachers-claim that the ahad hadith are self-sufficient sources of Islamic theology, laws, and ethics (Al-Albanee 2003, pp. 33-36). We shall examine this issue in more detail below when we examine Philip's view on ahad hadīth as sources of Islamic law, ethics and beliefs.

The concept of sunna etymologically has been defined as a "commendable straightforward manner of conducting oneself (al-sunnat al-tariqat al-mahmudat al-mustaqima)" (Ibn Manzur 1956, vol. 8, p. 226). During the first two centuries of Islam, it remained epistemologically and methodologically independent of the concept of a sahih (ahad) hadith and, in terms of its sources, was not restricted to the persona of the Prophet. Furthermore, the concept of sunna was conceptualized as a broad, ethico-behavioural, dynamic, and largely reason-inclusive one (Duderija 2012). However, by the middle of the third century of the Islamic calendar, the concept of sunna, due to the impetus of the ahl al-hadith movement that gave rise to the formulation and consolidation of classical hadith sciences ('ulüm ul hadìth), the concept of sunna became widely conflated with that of sahih ahad hadith (Duderija 2009). The sahih ahad hadith became accepted as a self-sufficient source of sunna in the matters of Islamic law and ethics (Duderija 2015) but not in matters of belief (Hansu 2009). Moreover, the mechanisms and criteria for a Prophetic hadīth to be considered 'sahīh,' as per classical 'ulüm ul hadìth such as those pertaining to isnād, were not entirely in place during the first two centuries of the Islamic calendar (Duderija 2009). Hence, any conflation of the concept of Prophetic sunna with that of sahin ahad hadith, as advocated by the proponents of NTS manhaj such as Philips, is highly problematic if not entirely ahistorical.

Now let us focus specifically on the views of Philips on the conceptual relationship between hadith and sunna. In the less than a page long section on the hadith and sunna in his book on Usul ul Hadith (Philips 2007), which is where we find his most sustained discussion on the subject matter, Philips starts the discussion on the relationship between hadith and sunna by noting the differences in meaning of the Sunna by lexicographers, muhaddithūn, Islamic jurists, and legal theorists as discussed in classical Islamic texts. The only citation he provides for the definition of sunna by muhaddithūn, Islamic jurists, and legal theorists is that of 'Ali. ${ }^{25}$ In the context of providing the definition of sunna as per the muhadithun, Philips makes an observation that, according to these scholars, the concept of sunna as a technical term is "synonymous with the term hadeeth" (Philips 2007, p. 7), and that the hadith

25 This work, however, is in essence, not a work on matters pertaining to hadith and its terminology and sciences; it is a work on the concept of Innovation or bida'ah in Islam. See 'Atiyyah (n.d.). 
are the "the containers in which the sunnah of the Prophet (r) was conveyed during his life time and after his death" (Ibid., p. 8), as per early classical Islamic scholarship. He also makes mention of other definitions of sunna as defined by the usūliyyūn and fuqaha without discussing any possible tensions that could arise between these approaches to the definition of sunna and his assertion that the concept of sunna and a sahīh ${ }^{26}$ hadīth are synonymous. In his Evolution of Fiqh book (Philips 1990), he also defines sunna in terms of that of the muhaddithūn and affirms sunna's position as an exposition of the Qur'ān and the clarifier and specifier of its intended meaning/s, as per classical Islamic legal theory. ${ }^{27}$

In relation to the question of the nature and the scope of the concept of sunna, Philips, following in the footsteps of the muhaddithūn's definition of sunna, states that:

Anything which the Prophet of Islam (r) said or did is considered to be a part of his Sunnah (i.e., way), which represents the practical application of Islam according to divine guidance.

(Ibid., p. 24)

Without attempting any differentiation between Prophet's saying and actions or their contextualization, Philips, citing Q 53:3-4 ${ }^{28}$, remarks further that “The Prophet's sayings and actions (the hadith) were primarily based on revelation from Allah and, as such, must be considered a fundamental source of guidance second only to the Qur'ān" (Ibid., p. 24). Moreover, in an online article entitled "Hadīth: The Second Fundamental Source of Guidance" under the heading "Revelation," he adds that "the Hadīth represents a personal source of divine guidance which Allah granted His Prophet (peace be upon him) which was similar in its nature to the Qur'ān itself." 29 He substantiates this claim by citing a hadith from the Abu Dawud's collection of hadith, according to which the prophet had reportedly stated that, apart from having been given the Qur'ān as a form of guidance, he was given something similar. ${ }^{30}$ For Philips, that "something similar" are the hadith which, based on our discussion above, are conflated with the concept of sunna and hadith, as viewed as a form of revelation itself.

Moreover, Philips uses this evidence to argue that the hadīth, by which he implies any 'sahīh' hadith, regardless of its epistemological value (and he does not use the word sunna anymore), are both "essential for the smooth running of the law courts in an Islamic State" and prime examples of ideal moral conduct, including personal life, character, and social interactions for Muslims until the Last Day. This is so because all of Prophet's judgments that have reached us in forms of hadith "were all based on revelation" and therefore "must be considered a primary source of principles by which judgments are carried out in an Islamic State" (Philips 2007, p. 6).

To further bolster his "hadīth-dependent concept of sunna," Philips, citing Q 33:21, which described the prophet Muhammad as 'uswah hasana' 31 for the believers, also argues that the prophet was "guided by revelation in his personal life" and therefore, his character and social interactions are to be considered as "prime examples of moral conduct for Muslims until the Last Day" and can only be accessed via a hadīth body of knowledge (Ibid., p. 6).

By completely conflating the concept of sunna and 'sahīh' hadīth, Philips also argues that hadīth are also necessary or indispensable in carrying out of basic Muslim religious responsibilities such as prayer and the annual polity tax (Ibid., p. 5). Philips, however, overlooks the possibility of following the sunna on these issues without any recourse to the hadith as, for example, argued by the contemporary

26 Philips follows the definition of sahih hadith as per the classical hadith scholar Ibn Salah. See Ibn al-Ṣalāh (2006).

27 "The term Sunnah refers to the statements and actions of Prophet Muhammad (s.w.), as well as the statements and actions of others done in his presence which did not meet his disapproval "but" exclude personal habits and customs of the Prophet (s.w.) which he did not instruct his followers to follow. In accordance with the doctrine of dual forms of revelation. Philips (1990, pp. 38-39, p. 42) views sunna (in form of hadith) as a form of revelation. On the classical view regarding the dual form of revelation see (Ibn Hazm 1987, p. 87).

28 In accordance with the broader NTS manhaj commitments delineated in the second section of the article.

29 http://www.newmuslim.net/quran-sunnah/hadith-the-second-fundamental-source-of-guidance/.

30 http://www.newmuslim.net/quran-sunnah/hadith-the-second-fundamental-source-of-guidance/.

31 Hence, this Quranic phrase does not use the terms sunna or hadith. 
scholar Ghamidi (n.d., pp. 18-19; pp. 61-64) or as per the early Maliki madhhab that considers sunna to be practice-based because its ultimate source and criterion is the practice ('amal) of the people of Madina (Wymann-Landgraf 2013; Dutton 2003). Based on the evidence presented above, we can conclude that Philips completely conflates the concept of a sahīh hadith, sunna, and divine guidance/revelation (Philips 2007, p. 24).

Philips does briefly discuss the difference between mutawātir and ahad hadīth. In reference to the criteria for meeting the mutawätir hadìth Philips makes reference, in the form of a footnote, to disagreements among classical Muslim scholars as to the minimum number of narrators required and cites, in the shortened form, what probably is the work of Muhy al-Din Yahya b. Sharaf al-Nawawi (d. 1277 CE) Tadrīb al-Rāwō fì Sharh Taqrīb al-Nawawī (commented on by Imam Al-Suyuti d. 1505 CE) to substantiate his claim that the preferred number is ten. Philips, however, does not provide full bibliographical information of this work, and it is most likely borrowed from the work of Azami (2003) (Philips 2007, p. 92). Despite his reference to the distinction between the mutawātir and ahad hadith categories, he does not explore any tensions these would have in terms of conceptualizing the concept of sunna or how this could undermine his own hadith-dependent concept of sunna.

\section{Bilal Philips on ahad hadīth}

As we discussed briefly above, the status of ahad hadith as self-sufficient sources of Islamic law, ethics, and, especially, belief has been one of the main sticking points in the works of Islamic legal theory and theology. Though in early Islam, 'sects' like early Kharijis and Mu'tazila rejected these hadith more or less in toto, all other groups, including the later versions of the same 'sects,' eventually accepted them (Melchert 2019; Hansu 2019). The only exception to this were the theologians who resisted the acceptance of ahad hadith as self-sufficient proofs in matters pertaining to creed (Hansu 2019).

In his discussion on ahad hadìth, Philips documents the various views regarding their epistemological value registering that most scholars hold that it is a hadith that does not impart definite knowledge (yaqin) on its own unless it is supported by extraneous or circumstantial evidence. He states further that "other scholars" held that an ahad hadith does constitute definite knowledge, which is derived thorough study and systematic deduction, as opposed to knowledge based on unequivocal proof provided by mutawātir narration. Revealing his commitment to the NTS manhaj, however, he approvingly cites Ahmad ibn Hanbal (d. 855 CE) and "others" who argue that ahad hadith can engender positive knowledge (yaqin). Philips cites the views of a Yemeni Salafi scholar Al-Shawkani (d.1839 CE), a Shafi'i theologian Al-Amidi (d.1233 CE), and the modernist jurist Abu Zahra (d.1974 CE), who formed the view that ahad hadith produce zann only (non-definitive knowledge), ${ }^{32}$ but he goes on to argue that the majority of jurists agree that ahad may establish a rule of law provided that: (i) It is related by a reliable narrator; (ii) the contents of the report are not repugnant to reason (iii) when other supportive evidence can be found in its favor or (iv) when there is nothing to oppose its contents, then acting upon ahad hadīth is obligatory (Philips 2007, p. 93). This assertion is in line with what we outlined above regarding the status of ahad hadith in mainstream Sunnism (Melchert 2019; Hansu 2019). Importantly, in respect to the validity of ahad hadith as self-sufficient sources of proof (dalī) in matters pertaining to 'aqī $d a$, Philips again while referring to the view of Abu Zahra, ${ }^{33}$ disagrees by stating:

The texts of the Qur'aan and the Sunnah, the way of the Companions, and the sayings of scholars are all clear evidence to the necessity of accepting hadeeth aahaad in all matters of religion, whether laws or 'aqeedah. To differentiate between them is an innovation (bid'ah) unknown among the Salaf. (Philips 2007, p. 93)

32 Their views were based on the understanding that this was the opinion of the majority of scholars according to Philips.

33 According to whom, the majority of Muslim scholars are of the view that they are not to be considered as self-sufficient sources. 
He goes on to cite the view of Al-Jawziyya (d. 1350 CE), a prominent proponents of pre-modern Salafism, from his 'Ilām al-muwaqqin,$^{34}$ and the opinion of a major authority of contemporary Salafis, Al-Albanee (2003, pp. 55-82), as supporting this viewpoint (Philips 2007, pp. 94-103).

\section{Bilal Philips on taqlīd and madhāhib}

Apart from the conceptual relationship between sunna and hadith bodies of knowledge, the concept of taqlīd-based hermeneutic in mainstream Sunni madhāhib occupies an important position in the thought of Philips. Like his views on hadith sunna dynamics presented in the previous section, his ideas about taqlīd that are found among the main four Sunni madhāhib are also revealing of his Salafi or NTS manhaj. His most systematic thinking on this issues can be found in a 150 page long booklet titled "Evolution of Figh: Islamic Law and the Madhhabs" (Philips 1990) that is used as a prescribed text in his IOU courses. Philips explains that the book's contents are based on the class notes he took and research papers Philips read for a graduate course on the history of Islamic legislation taught at the University of Riyadh.

Philips, in the preface to the book's third edition, clearly identifies that one of the main aims of the book is "to provide a theoretical framework for the reunification of the Madhhabs and an ideological basis for Islamic community work free from the divisive effects of Madhhab factionalism" (Ibid., p. 6). In the preface, he goes on to lament the fact that "unresolved contradictions" in rules inherited from the era of classical orthodox madhāhib pose problems not only for converts but also to all "thinking Muslims" (Ibid., p. 7). This practice of critiquing of the madhāhib is furthermore linked by Philips to his thesis of "stagnation" and "decline" in the Muslim world and the need "for the revival of Islam in its original purity and unity" (Ibid.).

Given his views on sunna and hadith discussed above, this revival must be evaluated as one based on the NTS or neo-ahl al-hadìth call for revival of sunna (ihyā al-sunna). As argued by Brown to the proponents of the NTS manhaj, the idea of ihya al-sunna, the revivification of and the return to Prophetic Sunna that emerged at the time when most of the Muslim world was under colonial rule, was to be achieved by insisting that only an unflinching adherence to the body of "authentic hadith" as defined by ahl al-hadìth manhaj constitutes ihyā al-sunna. Thus, the main purpose behind the call for ihya al-sunna was to undermine the madhhab-based approach to conceptualizing and interpreting the Islamic tradition, especially their concept of the nature and the scope of the concept of Sunna (Brown 1996, p. 20).

Moreover, Philips opines that the attempts to maintain the co-orthodoxy of all recognized madhāhib despite the unresolved "contradictions" between them are "undesirable." Equally so are the approaches to reforming the Islamic tradition on the basis of following the guidance in the Qur'ān and Sunna only. The reasons he gives for this are framed as follows:

The latter perpetuates that sectarianism which split the ranks of Muslims in the past and which continues to do so today. The former position of rejecting the Madhhabs in their entirety, and consequently the Fiqh of earlier generations, leads inevitably to extremism and deviation when those who rely exclusively on the Qur'aan and the Sunnah attempt to apply Sharee'ah law to new situations which were not specifically ruled on in either the Qur'aan or the Sunnah. Clearly, both of these outcomes are serious threats to the solidarity and purity of Islam. (Ibid., p. 8)

Philips' view $^{35}$ is that the solution to resolve this problem is to adhere to the rulings of early notable Muslim scholars because they "are more likely to represent the true intentions deducible from

34 But does not provide a full reference.

35 Based on the prophet's hadith that the best generations of Muslims are the first three generations. 
the Qur'aan and the Sunnah" and contain "important links and guidelines which cannot wisely be ignored in out [sic] study and continued application of Allaah's laws" (Ibid., p. 9).

Furthermore, in his critique of the finality of madhāhib doctrine, Philips argues that the totality of Islam or Islamic law cannot be attributed to any of the madhăhib that have existed and/or still exist. Faithful to his NTS manhaj, he also points out that the madhhab position is not infallible and that:

The only infallible Madhhab that deserves to be followed without any questions asked is that of the Prophet Muhammad himself (SW.). Only his interpretations of Sharee'ah can be considered divinely guided and meant to be followed until the last day of this world. All other Madhhabs are the result of human effort, and thus are subject to human error. (Ibid., p. 15)

With this statement, he clearly takes aim at the taqlīd-based hermeneutics of the classical madhāhib the criticism of which is a major feature of the NTS manhaj (Duderija 2011).

When discussing the evolution of figh during the times of the first four caliphs, Philips makes an important observation that each caliph had its own madhhab ${ }^{36}$ since "the final say in legal matters rested with them." However, he goes on to make a claim that "all legal decisions [of the caliphs] were subject to alteration on the basis of recorded statements or practices of the Prophet (s.w.) - that is, Hadeeth" (Philips 1990, p. 72). This claim is historically inaccurate, as these caliphs were not concerned with collecting hadith in any extensive way, nor did the isnād-based system exist at that time (Duderija 2009).

Furthermore, Philips traces the beginnings of deviation from "sunna'" and the creation of madhähib during the Umayyad period and attributes it specifically to the early rationalist school of thought, the ahl al-ra'y, that was based in Iraq (Melchert 1997) and whose scholars are said to have developed very strict conditions for accepting hadith and depended more on reason than on what Philips terms "narrated Sunna of the Prophet" (Philips 1990). Here, Philips subtly introduces an artificial distinction between the views of the ahl al-ra'y and the concept of sunna that, in reality, did not exist. In actual fact, not only did the ahl al-ra'y have their own concept of sunna (Melchert 1997, pp. 1-48), the very concept of sunna during the formative period of Islam (some two hundred years or so) was constitutive of reason and did not depend on narrations (Duderija 2009, 2012, 2015).

Moreover, in the context of discussing the development of figh during the Abbasid times, Philips argues that, over time, the lack of rigidity and sectarianism that characterized the time of the four founding fathers of Sunni madhăhib was lost, and that, from the middle of the ninth century common era, "the opinions of the Madhhabs were gradually given precedence over one of the primary sources of Islamic law, namely the Sunnah" in form of "collected and compiled in books of Hadeeth" (Philips 1990, pp. 64-66). Philips makes no mention of Imam Malik's concept of 'amal ahl al-madina as the main source of sunna during this time, nor does he make note of the concept of sunnat mahfüzat marüfa that existed in Iraq among the early Hanafis (Duderija 2012). ${ }^{37}$ Furthermore, Philips tries to undermine the madhāhib-based approaches to sunna and their broader taqlīd-based hermeneutic by suggestion that they abandoned sunna itself entirely, simply on the basis of "de-emphasizing of the importance of Hadeeth, or by neglecting to mention their sources and their levels of authenticity" (Philips 1990, p. 66). Moreover, he uses certain isolated hadīth-based reports suggesting that Abu Hanifa (d. 767 CE) himself had stated that his madhhab (Ibid., pp. 63,126$)^{38}$ is based on hadith without understanding the significance of the concept of sunnat mahfüzat marüfa as a methodological and hermeneutical tool used in early Hanafism in filtering hadith from sunna (Duderija 2012). Importantly, he does not mention

36 As documented by Duderija (2015), each caliph was actually considered to have introduced new sunna, and each was considered as source of sunna.

37 The only distinction he makes is that classical Hanafi madhhab stipulated that, for a hadith to be sahih, it also had to be widely known. (Philips 2007, p. 74).

38 However, Sadeghi notes as follows: "For Abu Hanifa and Al-Shaybani, not only were the Hadith not a primary source of law in practice but that they were also possibly not always binding in theory either." Sadeghi (2004, p. 139; cf. Duderija 2009). 
Imam Malik (d. $795 \mathrm{CE}$ ) as having stated that his madhhab was based on hadith. ${ }^{39}$ Philips does make note of the fact that both the Hanafi and Malik madhāhib stipulated conditions beyond the 'sahin ahad hadith' concept of sunna that Philips defends as the 'proper' sunna by pointing out that, in the case of Hanafis, the hadith had also to be mashhür (i.e., well known) and, in the case of Malikis, that it could not contradict the customary practice of Medina as the actual sources of sunna. He, however, fails to understand or disclose the full implications of the sunna hermeneutic of these madhāhib that was not reduced on that of 'sahin ahad' hadìth and that they worked with or possessed a hadith-independent concept of sunna (Philips 1990, pp. 74, 79). This is a major oversight on behalf of Philips because the taqlīd-based hermeneutic of these madhāhib is based on this very important difference in the way the concept of sunna itself is understood and conceptualized and is the backbone of their broader legal theory based on taqlìd (Duderija 2012, 2015).

Moreover, in a further attempt to discredit the taqlidd-based hermeneutic of the madhāhib as a deviation from the ahl al hadith manhaj-based concept of 'sunna,' Philips argues that what are today considered as the four mainstream Sunni madhāhib are essentially non commensurate and "antagonistic entities" with "insurmountable differences" that breed "sectarianism" and "fanaticism" that have caused the stagnation and the decline of ijtihäd and Islamic law in general (Philips 1990, p. 72). In the book's section titled "Imams and Taqlīd," Philips again defends the idea of the need for fighand madhhab-based approach to Islam in principle but takes issue with the concept of finality and "infallibility" of the four mainstream madhāhib and calls for their unification on the basis of his neo- ahl al-hadith manhaj. In this respect, he forms the view that the founders of the four madhāhib themselves were against 'taqli $d$ '-based hermeneutics of the madhăhib, and that the adherence to the madhhab-based taqlïd hermeneutic borders on shirk. In his words:

Yet, till today, many people feel that if an authentic Hadeeth should be discarded because accepting it would mean declaring that the Imaam of one's Madhhab was mistaken in his ruling which, in their opinion, is an act of disrespect akin to blasphemy. Little do they realize that their preference of their Imaam's opinion over the Prophet's (s.w.) statement is itself in total opposition to the stand taken by their own Imaam and is in fact bordering on a form of Shirk known as "Shirk fee Tawheed al-Ittibaa'," that is sharing the unquestioned following which belongs only to the Prophet (s.w.). For in the declaration of one's Islam (there is no god but Allaah and Muhammad is the messenger of Allaah), the Prophet (s.w.) is accepted as being the only person who should be followed unquestioningly, since following him is equivalent to following Allaah. (Ibid., p. 125)

Elsewhere in the book (Ibid., p. 131), after having discussed what he considers to be the actual views of the four great Imams on hadìth and sunna that in his view align with the ahl al-hadith/NTS manhaj, he writes as follows:

The above-mentioned quotations were only a few of the many sayings of the Four Imaams and their students in which they demanded strict adherence to the Hadeeths and prohibited the blind imitation of their opinions, may Allaah be pleased with them. Their statements

39 This is significant because, for Imam Malik, as noted above, it was the 'amal ahl al-madina that is the source of sunna and the criterion of accepting or rejection hadith eve if they had an authentic isnad. Moreover, the epistemological value of 'amal-based sunna is much higher than that of isolated hadith. See (Wymann-Landgraf 2013; Dutton 2003). Philips does admit that there are no hadith or saying attributed to Imam Malik that suggest that his madhhab is also based on hadith, but Philips still argues that this indeed is the case on a basis of a single hadith, according to which Imam Malik changed his ruling on one aspect of ablution in light of a "good hadith" he was not aware of. Philips also refers to the work of the hadith scholar Ibn Abi Hatim, according to who Malik reportedly stated that "Verily I am only a man, I err and am at times correct; so thoroughly investigate my opinions, them take whatever agrees with the Book and the Sunnah and reject whatever contradicts them." Philips comments that this is evidence that Imam Malik preferred Quran and hadith over his opinion. It is crucial, however, that Philips in his comment does not use the actual word sunna that is in the quote but replaces it with the word hadith to suggest that these two are the same from the perspective of Malik. However, for reasons explained in the main text above, this is not true. 
are perfectly clear and leave no room for misinterpretation or apologetic explanations. Therefore, whoever adheres to the Sunnah, even if he finds himself in conflict with some of the opinions of the Imaam of his Madh-hab will not be opposed to the spirit of that Madhhabs simultaneously with a firm grip "on the rope of Allaah." Conversely, to discard certain reliable Hadeeths simply because they contradict some of the opinions of the Imaams is to be in total opposition to the position taken by the Imaams themselves. Moreover, the rejection of reliable Hadeeths is in opposition to Allaah and His messenger ... ". (Ibid., p. 130)

However, as in the case of his ideas regarding the concept of sunna, the views of Philips do not accurate portray the concept of taqlīd- or taqlid-based hermeneutics of the madhähib. For example, in his discussion of the principle of taqli $d$ and its function in Islamic jurisprudence, Jackson argues that taqli $d$ is not so much related to the notion of it precluding novel interpretations, as it is commonly held, but is rather a means of validating jurist's legal interpretation 'retrojectively,' i.e., by searching to back the interpretation with an established source of authority (Jackson 2006). Furthermore, Hallaq considers that taqlìd not only functioned as an effective means of legal change, but it did so even more than ijtihād itself because, unlike $i j t i h \bar{a} d$, taqlìd-based interpretations were seen as to be loyal to and continuous with the ongoing tradition (Hallaq 2001, p. 239). Taqli dis, therefore, to be seen as a hermeneutical mechanism whereby, rather than abandoning existing legal theory rules in favor of new interpretations of the relevant textual indicants found in the Qur'ān and hadīth without precedent, a jurist develops new interpretations within the framework of the established madhhab-based hermeneutic. Hallaq forms a similar view by seeing taqlīd as a reasoned defense of a particular legal doctrine based on a madhhab's overall methodology and hermeneutic (Ibid., $x$-xi). This allegiance to the madhhab-based legal theory hermeneutic by the means of taqlid was derived from the consensus of scholars belonging to a particular madhhab. ${ }^{40}$ This legal mechanism's primary purpose was to ensure that the legal opinion of a jurist is able to gain wide(er) acceptance by embedding it into the 'sacred past.' For the madhhab-based approach, this consensus of madhhab scholars is the ultimate criterion in determining the compliance or otherwise of a particular legal principle (Brown 1996, p. 20) with the Qur'ān and the Sunna and not the hadith, as in the case of the ahl al-hadith manhaj. Moreover, as explained above, it should be reiterated that the taqli $d$-based hermeneutic itself is based on a hadith-independent concept of sunna of the madhāhib.

As such, the above described approach to sunna/hadith and understanding of the taqlìd-based hermeneutic of madhāhib by Philips falls squarely into the neo-ahl al-hadith /NTS camp that Duderija elsewhere described as follows:

The ahl al-hadith manhaj rejects the broader, hierarchical hermeneutic upon which the practice of taqlīd is based. The proponents of the ahl al-hadith manhaj argue, instead, for an unmediated return to the Qur'ān and Sunna in the form of Qur'ān and hadìth-based texts. Taqlīd, according to the ahl-hadīth approach, is an innovation, bida'ah, and a deviation from Sunna. Instead, the ahl-hadith consider that the uncontested adherence to hadith, as the sole vehicle for the perpetuation and depository of Sunna, termed ittiba', is the only way of remaining truthful to the Prophet's Sunna. (Duderija 2011, p. 33)

Suggestively, Philips, in several places in the Evolution of Figh book defends the concept of ittiba' that he translates as "reasoned following." He contrasts ittiba' with the concept of taqlid that Philips conveniently defines as the "blind following" of madhhabs and argues that ittiba' conceptualized as a method (manhaj) is based on adherence to the "early interpretations [that] were founded on the Prophet's (s.w.) divine inspiration and his divinely guided life style" as per the Prophet's hadith that the best generations of Muslims are the first three (Philips 1990, pp. 114, 133-34). In other words,

40 This consensus should not be confused with the later definition of it in form of ijma' but should be understood in terms of the agreed living practice constituting sunna. (Hallaq 2005, pp. 110-12). 
Philips uses a 'sahīh ahad hadīth' as per classical 'ulum ul hadith (therefore a construct from the third century Islamic calendar) sciences to defend his hadith-based concept of sunna and ittiba'-based sunna hermeneutic, as well as to cast aspersions on the taqlīd-based legal theory of the madhāhib.

Importantly, when discussing differences in rulings between the madhähib Philips does not identify or consider the differences in the very concept of sunna between the madhähib discussed above as one of these, since he erroneously assumes that all of the madhähib operated on the same concept of sunna. In actual fact, Philips, throughout his Usul-ul Hadith and Evolution of Figh books, not only conflates the concept of sunna with that of 'sahin' ahad hadith (as defined by classical 'ulum ul hadith) but, as noted above, at times imposes it onto the other madhähib, in the sense that the founders of the four main surviving madhăhib are also described as adhering to the same.

Another piece of evidence that situates Philips as a proponent of NTS manhaj can be found in his discussion on premodern and modern Muslim reformers who were opposed to the taqlid-based hermeneutics of the madhähib. For example, Philips identifies the great champion of anti-taqlide-based hermeneutics of the madhāhib, Ibn Taymiyya (d. 1328 CE) as the "foremost among the reformers" and "one of the greatest scholars of his time" alongside his student Ibn Jawziyya, the Quranic exegete Ibn Kathir (d. 1373), the Yemeni scholar Al-Shawqani (d. 1839 CE), the Indian hadith scholar Shah Waliullah (d. 1762 CE), and Al-Albani, "the great hadith scholar" (Ibid., pp. 117-20).

Furthermore, Philips also mentions the modernist scholars such as Al-Afghani (d.1897 CE) and 'Abduh (d. 1905 CE) as also rejecting taqlid, but he criticizes the former for "elevate[ing] the human mind and its logical deductions to a level equal to that of Divine Revelation" and the latter for his "leaning toward extreme modernism" (Ibid., p. 119). In other words, both are criticized because they deviated from the NTS manhaj and its ittiba'-based (sunna) hermeneutic.

In a continued effort to disgrace the institution of taqli d and its hermeneutic, Philips laments that in the contemporary major centers of Islamic learning like Al-Azhar, the madhhab-based approach remains firmly entrenched, and that "the great books of Hadeeth are read more for the blessing than for the revelation of truth" or are explained away or reinterpreted to align with the madhhab position (Ibid., p. 121).

Finally, Philips' admiration of both pre-modern and modern ahl al-hadith movements resisting the taqlìd-based hermeneutics of the madhāhib is clearly expressed in the following passage:

Similarly, the term Ahl-i-Hadeeth (Ar. Ahl al-Hadeeth) was a title of respect and praise given to scholars in the past who, like Imaam Maalik, devoted much time and effort to the specialized study of Hadeeth. Towards the end of the nineteenth century, this title was adopted by a reform movement in India and Pakistan, which called for a return to the Qur'aan and the Hadeeth as the basis of Fiqh and which opposed the dogmatic adherence to Madhhabs. However, present day Madhhab fanaticism and sectarianism have distorted the meaning of the term Ahl-i-Hadeeth to apply to one who fanatically opposes the following of any of the Madhhabs. (Ibid., p. 136)

In summary, both in his approach to conceptualizing the relationship between sunna and hadith and to that of the taqlīd-based hermeneutic of the madhähib, Philips' views are entirely in accordance with the opinions of NTS scholars and are premised on the same manhaj.

Apart from his views on sunna, hadith, and taqlid, another useful heuristic assisting us in identifying Philips as a proponent of the NTS manhaj is by examining Philip's views on the methodology of Qur'ānic exegesis (tafsīr). We turn to his views on this subject matter next.

\section{Philips on the Correct Methodology of tafssir}

The final lens through which we want to situate Philips approach to the Islamic intellectual tradition are his views on what constitutes the correct manhaj in relation to tafsitr. Differences in approaches to tafsi $i$, in addition to those relating to the nature of the concept of sunna and its relationship with hadith discussed above, are evident in the conceptualizing and interpreting of the Qur'ān and Qur'ān-based 
sciences (i.e., 'ulum-ul Qur'ān) and the role of reason and reason-based opinion $\left(r a^{\prime} y\right)$ in them. As a direct consequence of the above described conflation of hadīth and sunna bodies of knowledge, the Qur'ānic sciences pertaining to chronology, modes, and occasions of revelation; the Qur'ān's collection and transmission; and the formal presentation of the Qur'ān's definite recension, prosody, and textual units, exegesis, and historical notations are all epistemologically constrained by the body of knowledge that underpins traditional hadìth-based sciences, the 'ulum-ul hadìth. ${ }^{41}$ Therefore, the NTS-based Qur'ānic exegesis ( $t a f s i r)$ is characterized by what we could term an unflinching epistemological addiction to hadith-based and hadith-constrained bodies of knowledge. This approach is commonly known as

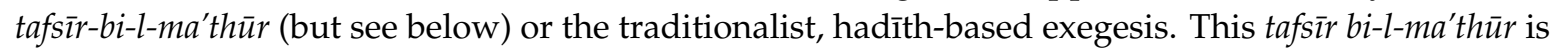
just one of many tafsir categories that exist in the broader Islamic tradition. Others include theological, literary-rhetorical, mystical, reason/opinion-based (tafsìr bi-l-ra'y), literary-philological, Shi'i, esoteric, or juristic exegesis (Goldziher 1952; Abdul-Raof 2010).

Importantly, the neat delineation between various tafsir genres have always been contested and are conceptualized and appropriated by different actors differently. As noted by Saleh:

The Sunnīs would come up with their own term for their approach to the interpretation of the Qur'ān, al-tafsīr bi'l-ilm, interpretation by knowledge; the problem has always been that one was not sure what exactly this term means. Yet, it was never perceived as being restricted to the early three generations as such. The Sunnī paradigm, more importantly, has a negative term to describe the approach of their enemies, al-tafsīr bi'l-ray, and Sunnīs supposedly did not engage in this willful distortion of God's word. Needless to say, the distinction between the two modes turned out to be a mirage, insofar as if one belonged to the approved list of Sunnī authorities, one was a practitioner of al-tafsīr bi'l-ilm. If one was not, one was then doing the other! (Saleh 2010, p. 23)

Similarly, Mubarak, in her careful analysis of Ibn Ashur's tafsìr, al-Tahrìr wa'l-tanwwìr, reinforces the point made by Saleh regarding the artificial delineation between tafsīr bi'l-ray and tafsìr bi'l-mathūr by stating that according to Ibn Ashur:

(1) Not all opinions transmitted from the Companions or Successors are from the Prophet, but [these] have often been formulated through their own knowledge and deduction; (2) therefore, what is commonly assumed to be tafsīr bi'l-mathūr is in fact tafsīr bi'l-ray; and (3) that this deductive reasoning constitutes the basis of the formation of legal doctrine (figh) in the first three centuries of Islamic history. (Mubarak 2018, p. 5)

It is also important to note that although there were hadīth-based mufassirūn (exegetes) within each madhhab, the overall madhhab-based tafsir manhaj included other approaches too and allowed more scope for reason and reason-based opinion $\left(r a^{\prime} y\right)$ in it (Ahmed 1997, pp. 113-79). Moreover, scholars associated with a particular madhhab also approached Quranic exegesis on the basis of its taqlìd-based hermeneutic as discussed above.

Having outlined the basic contours of tafsir genres, let us look more carefully at the positions taken by Philips. Philips views on the correct methodology of $t a f s i r$ are most systematically developed in his booklet titled 'Usool at-tafseer" (Philips n.d.), which is also used as an instructional text for his IOU courses. We are here only interested in discussing his ideas regarding the correct methodology of Qur'ānic interpretation, which is also the main aims of the book as identified by Philips. In this regard, he hopes to provide a "step-by-step methodology of interpreting the Qur'aan to ensure that interpretations are not merely the result of human whims and fancies" (Ibid., p. 2).

The first indication of his views regarding the correct manhaj when it comes to tafsì comes in the context of his discussion of their transmission. Philips writes

41 Remaining Qur'anic sciences, such as rhetoric and style or syntax, deal with aspects that are internal to Qur'an itself and largely do not rely on transmitted body of knowledge in form of hadith. 
Works of tafseer soon began to reflect various trends of thought in Muslim society. By the eleventh and twelfth centuries, the major works of Greek philosophy and science that had been translated in the previous centuries began to have an effect on all of the various Islamic fields of study. Philosophical schools of thought like that of the Mu'tazilees (Rationalists) had evolved which boldly threatened pure Islamic thought. Tafseers full of philosophical and scientific terminology, like al-Kash-shaaf of az-Zamakhsharee (1075-1144 CE/467-538 AH) or Mafaateeh al-Ghayb of Fakhrud-Deen ar-Raazee (1149-1210 CE/544-606 AH), and tafseers expressing the thoughts of various heretical sects also appeared during this period. For example, the Twelver Shee'ah tafseer of Mullah Muhsin al-Kaash made the verses of the Qur'aan speak of twelve infallible imaams, the imaginary walaayah (governorship) of the Prophet's son-in-law 'Alee, and the claimed apostasy of all of the Prophet's companions except a handful; the Soofee tafseer of Ibn al-'Arabee (d. 1240 CE/638 AH) made Qur'aanic verses voice his pantheistic ideology of Allaah being all and all being Allaah. (Ibid., p. 12)

From this quote alone, it is evident that Philips takes issue with what he considers to be the rationalist-philosophical, scientific, sectarian (i.e., Shi'i), and Sufi approaches to tafsir as a deviation from tafsir "based on authentic narration" (Ibid.), by which he, of course, implies the ittiba'-based NTS manhaj. Furthermore, Philips argues that the various sects he lists engaged in tafsir in highly subjectivist ways and essentially for 'sectarian' purposes rather than aiming to arrive at objective meaning/s. This view can be gleaned from the following assertion:

The authors of these tafseers stretched the meanings of the verses to affirm the thoughts and ideas of their respective sects or schools and rebut those of others. Thus, the primary role of tafseer, that of explaining religious instruction contained in the verses, was lost. (Ibid., p. 13)

Tellingly, Philips exempts the tafsìr of Ibn Kathir, which is heavily hadith-based, from the above and describes it as "highly acclaimed" (Ibid., p. 14) and as emblematic of the ahl al-hadith manhaj approach to tafsir . Saleh, in his overview of the historiography of tafsìr in Arabic, notes the predominance of and the prime position awarded to Ibn Kathir's tafsīr in the contemporary period, especially among the Salafi circles:

When one now surveys the Islamic world and tries to ascertain what is the most popular Qur'ān commentary, it becomes clear that it is Ibn Kathīr's commentary that is now playing the role that was once played by al-Bayḍāwī's. Even al-Ṭabarī is unable to compete with Ibn Kathīr. Ibn Kathīr's tafsīr is so popular that one tends to forget how recent his ascent was in the Islamic world. (Saleh 2010, p. 15)

Saleh ultimately anchors the privileged hermeneutical position of Salafi-based tafsir such as that of Ibn Kathir in the modern era as reflected in the views of Philips "enforcing a sort of complete hegemony on hermeneutical theorisation" to the efforts of Ibn Taymiyya, especially his work of tafsìr titled Muqadimma fì Usūl -ul tafsìr (Ibid., p. 16).

Interestingly, despite finding some 'faults' in the tafsīr of Sayyid Qutb pertaining to certain aspects of his conceptualization of the concept of tawhìd, Philips praises the work for "its vigorous Islamic critique of the flaws of secularism and the European civilization that spawned it at a time when most Muslims were apologetic about Islam" (Philips n.d., p. 15). This qualified endorsement of Qutb, the father of modern political Salafism, as we will see in the next section, will expose Philips to criticism within his own Salafi community.

In no unclear terms, Philips identifies and advocates that the best form of tafsir is that based on narrations, the "tafsīr bi-l-riwāya/ma'thūr'," as it minimises "subjective opinion" and bias. In his words:

The authors of such tafseers also avoided unfounded interpretations and unnecessary explanations and always accepted authentic narrations. This is not to say that such tafseers are totally free of personal judgment and opinion, for any tafseer, of necessity, must reflect 
the opinion of the individual who compiles it. But in this case, personal opinion was kept to a minimum. (Ibid., p. 35)

Philips' views on the correct methodology of tafsìr can also be distilled from his discussion regarding the distinction between the concepts of tafsir and tawil. He argues that, over time, tawil lost its actual meaning of a legitimate interpretation/explanation and was used to introduce all kinds of 'heretical' ones instead, such as those that departed from the 'obvious' to contextual or metaphorical meanings (Ibid., pp. 17-18). We are, of course, to understand this statement in light of Philip's adherence to the NTS manhaj as to what would constitute a legitimate and 'heretical' tawil.

Importantly, Philips argues, without providing any references, that the first two generations of Muslims have been able to preserve the original tafsìr $/$ meanings of the Qur'ān from that of the Prophet (Ibid., p. 19). Given what we know about Philips overall manhaj commitments, this original preservation of tafsìr is taken to be in the form of sahih ahad hadith. This view, however, is at odds with what we outlined in relation to the developed of the concept of an authentic hadith that took at least two hundred years to develop and take root (Duderija 2009), as did the category of tafsìr bi-l-riwāya (Leemhius 1988; Motzki 2003).

Philips goes on to outline the hierarchy of sources of tafsir (and in essence follows that of Ibn Kathir) and orders them in the following manner: By the Qur'ān itself; by sunna (by which he means sahīh ahad hadīth); by athār (i.e., opinions of the Companions); and by language/linguistically. In actual fact, he refers to (only) this method as constituting tafsīr bi-l-riwāya/bi-l-ma'thūr (Ibid., pp. 20-26). He adds that beyond these "there is little room for argument," and that any additional sources such as tafsir "based on opinion" are only valid insofar they do not contradict meanings derived from the first four sources. In fact, Philips cites the hadith that reportedly goes to the prophet, according to which he forbade the use of "reason-based tafsīr" as a form of disbelief ( $k$ ufr) (Ibid., pp. 27-28).

Moreover, when discussing the correct parameters necessary for arriving at correct tafsì from the perspective of the individual exegete (mufassir), Philips reveals his NTS manhaj commitment by stipulating these as follows. First, the exegete must adhere to the correct belief. To Philips, this means steering away from "the damaging influence of philosophies, schools of thought, movements, and sects" as well as being free from "preconceived ideas and notions" as these will "invariably lead to misinterpretations and sectarian explanations" (Ibid., p. 33). With respect to the mufassir's manhaj, Philips identifies the four-tier methodology outlined above as the only correct one. Finally, in relation to mufassir's possession of 'correct knowledge,' Philips emphasizes the importance of mastering of classical Arabic, sciences of hadīth, figh usūl al figh and highlights the paramount need for the mufassir to be able to discern which hadith are authentic and which are not (Ibid.). This last point is hardly surprising given the elevated status Philips awards to narration-based tafsitr, as well as his broader manhaj commitments as a proponent of NTS described in this article.

In summary, as in the case of his views on sunna, hadith, and madhähib/taqlìd, Philips considers that the only correct methodology of tafsir is to be only found in adhering to the NTS manhaj.

In what follows, we examine one example of an internal critique that has been levelled at Philips by fellow NTS proponents in the West that sheds further light on not only Philips' own manhaj-based commitments but also provides us with an important vista into the inner, often volatile, and acrimonious manhaj-based disagreements that occur between not only Salafis in the West but also among Salafis globally (Meijer 2009; Maher 2016).

\section{Critique of Bilal Philips' Ideas by Salafis in the West}

To better understand the internal Salafi criticism of Philips' interpretational approach, it is helpful to briefly refer to the (extensive) scholarship on various forms of Salafism that documents differences in manāhij between various Salafi groups. Hamid, in his recent overview of salafi groups in the UK, describes the situation in the following manner: 
Salafis across the world are by no means a unified religious trend and display a number of internal divisions and scholarly points of view. The divergences stem from the different perspectives on how to respond to modernity and the socio-political challenges facing Muslims. This sometimes pits different factions against each other over what constitutes the correct manhaj .... (Hamid 2016, p. 59)

As highlighted by Hamid above, the disputes and fragmentations between salafis, not just in the West but also globally, are most commonly based on issues pertaining to what is considered as the correct manhaj when responding to certain theological, legal, ethical, and contemporary socio-political issues, especially those relation to use of legitimate form of violence in achieving politico-religious aims (Meijer 2009). Wiktorowicz (2006, pp. 207-39), in his widely cited work, developed a typology of Salafis that groups them into those $\mathrm{w}$ ho are 'apolitical' ${ }^{42}$ and focus primarily on theological issues, especially those pertaining to the correct creed ('aqida) (puritans); those who have a more politically engaging or activist mindset (politicos) ${ }^{43}$; and those who engage extremist violence ${ }^{44}$ (jihadists) (Ibid.)

In what follows, we will refer to exchange between Abu Khadeejah, a former associate of Philips living in the UK (Hamid 2016, pp. 50-68), and Philips that exemplifies some of the divisions and factionalism among Salafis outlined above. As alluded to above, the purpose behind discussing the Abu Khadeejah versus Philips 'incident' is not meant to be an exhaustive treatment of intra-Salafi factionalism in the West. It, however, allows us:

(i) To point out that this factionalism does exist and that it largely revolves around manhaj-based issues.

(ii) To have a more informed understanding of Philip's own manhaj commitments and how they differ/or are similar to from other (quiestist) Salafis in the West.

In the context of discussing the views of Philips on taqlid, we already made mention of the fact that he expressed positive viewpoints about some of the ideas Sayyid Qutb, a prominent intellectual figure in political Salafi circles. This seems to be one of the reasons why Abu Khadeejah, whom Hamid considers a proponent of puritan Salafism or a "Madkhali' (Hamid 2016), in his short online post/article 'Giving Da'wah to the Innovators, its Nature, Conditions, and Context,' identifies Philips as one of the people who have stayed away from an authentically Salafi manhaj:

We took issue and oppose Bilal Philips with his open attachments to the likes of Ali Tamimi, Zarabozo, JIMAS ${ }^{45}$, and others known for their hizbiyyah and deviation, and going to the platforms of the likes of these people-all of whom are known to be amongst the Harakiyyoon, upon the manhaj of Safar and Salman and Abdur-Rahmaan Abdul-Khaaliq and others. (Abdul-Wahid 2002)

Elsewhere, Abu Khadeejah, in his short article published on his website revealingly titled "Bilal Philips the Deceitful Defender of Ahl ul Bida," has singled out Philips specifically as a proponent of innovation bida' $a$ (usually understood to be an antonym of sunna) and a proponent of "Ikhwaanee Manhaj" ${ }^{\prime 6}$ that has led many Salafi youth away from the authentic Salafi manhaj. ${ }^{47}$ He lists a number of quotes by Philips dating back to the early 2000s, accusing Philips of: (i) Being a proponent of a

42 Or, more precisely, those who maintain political status quo, especially in the context of Saudi Arabia and the Gulf States. As such, they are also known as Madkhalees, followers of the quietist Saudi Arabian scholar, Al-Madkhalee (b. 1931), a student of Al-Albani and Bin Bazz. See (Hamid 2016, pp. 50-68).

43 Or those who challenge the political status quo but largely refrain from violence. They are also referred to as harakis (activists) and have links to certain conservative strands in the Muslim Brotherhood. In the Saudi Arabian context, they are associated with the Sahwa movement (Hamid 2016).

44 They are also known as takfirist and consider current Muslim governments as apostate (murtad) and are committed to never ending jihad against western governments (Hamid 2016).

45 Jamiat Ihyaa Minhaaj al-Sunnah.

46 Meaning that of 'political Salafis' or those sympathetic to the Muslim brotherhood.

47 https://www.abukhadeejah.com/bilal-philips-the-deceitful-defender-of-ahlul-bidah/. 
"revolutionary manhaj" of the likes of H. Al-Bana the S. Qutb and A. Mawdudi; (ii) as someone who engages in $t a^{\prime} w i l^{48}$; and (iii) that, in some of his views, Philips departs from the opinions of Al-Albani and Al-Uthaymin (Ibid.).

Bemoaning this situation of intra-salafi factionalism and infighting, Philips wrote a rebuttal of the accusations made about him by Abu Khadeejah on his personal website under the tab "Reply to Critics." ${ }^{49}$ In his response, Philips states that the "path of true guidance, i.e., Salafiyyah, was never intended to be an exclusive club, in which certain individuals can grant membership and confiscate it from whomsoever they please." He also adds that such an attitude resembles the very 'factionalism' that true Salafis are trying to curb. While Philips recognizes that there are people out there who "are masquerading as Salafees who really do need to be exposed," he insists that he is not one of them. Adopting a more confrontational tone, Philips goes on to mention that there is a "vocal minority" among English speaking Salafis "with limited knowledge" who have "taken it upon themselves to act as the ultimate judges of common Muslims and students of knowledge" as to who does and does not qualify as a Salafi. Anyone who disagrees with them, we are told further, is labelled as falling outside of the Salafi manhaj fold. ${ }^{50}$ Philips complains that even the process of labelling and excluding itself is considered by these critics to be part of the correct manhaj itself. Implicitly referring to the article "Bilal Philips as Deceitful Proponent of Ahlul Bida'" that cites excerpts of Philip's writings over the years, Philips characterizes the efforts of his critics as follows:

They have made it a hobby to search for ambiguous statements of the popular du'aat, and then they distort and twist the statements to suit their personal agendas and publicize them in other than their correct context. They then label the da'ee or student of knowledge as being of ahlul bid'ah wal ahwaa (the people of innovation and desires) and relegate him to off-theminhaj.com. In addition to that, anyone who knows or affiliates with any of the people crossed off the list also gets the boot, and anyone who knows anyone who knows anyone from those they've labelled also gets labelled a deviant. (Ibid.)

Furthermore, again suggestively revealing his NTS manhaj commitments, Philips advises his critics to:

Spend their time beneficially, learning the basics, studying Arabic, tajweed, the classic works of 'aqeedah, such as al-'Itisaam, al-Usool ath-Thalaathah, Kitaab at-Tawheed, al-'Aqeedah al-Waasitiyyah, al-'Aqeedah at-Tahaawiyyah, etc., under scholars in the original Arabic. And, rather than trying to take some quotes here and there from great scholars like Shaykhs Nasirud-Deen al-Albaanee, Bin Baaz, 'Uthaymeen, and Muqbil, may Allaah have mercy on them all, I recommend that they actually listen to and study their tapes. (Ibid.)

Moreover, when examining his specific rebuttal of Abu Khadeejah's accusations, we can adduce additional evidence provided by Philips in form of an explanation or justification as to why he should be considered to be on the correct 'puritan' Salafi manhaj of the scholars like Al-Albani and his students who have remained faithful to his manhaj. In it, he also "declares his freedom" from "the manhaj of groups like Jamaati Islaami, the Ikhwaan, Hizb at-Tahreer, Jamaa'at Tableegh, etc."

Elsewhere in the rebuttal, Philips expresses his great admiration for the major authority on hadith for contemporary Salafis, N. Al-Albani and his manhaj as follows:

I currently have over 500 tapes of Shaykh al-Albaanee, from which I've listened to nearly 200, and am still listening (daily), not to mention over 200 of his earlier tapes which I listened to

48 See our discussion above.

49 http://bilalphilips.com/reply-to-critics/.

50 A more detailed response to the criticism of Abu Khadijah can be found on Bilal Philips' official website: http://bilalphilips. com/reply-to-critics/. 
in Saudi Arabia prior to emigrating to the Emirates. He is amongst my greatest role models, and Allaah knows I love him and his minhaj. He was indeed a great man. (Ibid.)

In the light of the arguments presented in the rebuttal of his fellow Salafi community it is clear that Philips considers himself as the proponent of the what Wictorowiz terms 'quietist' Salafism.

\section{Conclusions}

In conclusion, the focus of this article was to situate the interpretational approach (manhaj) of Philips and provide reasons why his ideas are important in understanding the Salafi movement/s in the West. Such an approach was justified by the fact that, to understand Salafism as an intellectual/scholarly phenomenon either in the West or elsewhere, it is essential to understand its overall positioning in relation to the Islamic intellectual history and the major fault lines that have developed within it. Given that many of Philip's own writings directly discuss this manhaj-based approach to Salafism, to understand Salafism in the West as an intellectual discourse with deep roots in the Islamic intellectual tradition, it was essential to focus and shine light on Philip's own approach to or understanding of Salafism, especially given that no other existing work either on Bilal Philips or Salafism in the West does so from this perspective. In this respect, the article demonstrated that the approach of Philips is entirely in accordance with that of NTS or 'puritan'/quietist Salafism associated with the most authoritative contemporary Saudi scholars such as bin Baz and Al-Albani. As such, the spread of Philips ideas among the Salafi community in the West can be seen as largely strengthening its puritan/quietist Salafi version. However, this claim is not beyond contestation. As discussed in the final part of the article Philips' adherence to the 'true' quietist manhaj has been disputed among a section of Salafi community in the West, exposing the internal factionalism and the contentedness of the very category of (puritan) Salafism and what constitutes its true manhaj. Thereby, this section of the article assisted us in understanding the often fractious dynamics pertaining to the nature and development of Salafi thought in the West that are deeply rooted in the Islamic interpretive tradition and are part of ongoing and often volatile global Salafi conversations as to what constitutes the correct Salafi methodology (manhaj), including among the salafi-jihadists (Meijer 2009; Maher 2016). Finally, the views and the ideas of Philips and their significance for the Salafi movements in the West ought to be evaluated from the broader perspective of western Salafis' scholarly deferral to and dependence on what, at any point in time, are considered to be the major authorities of the 'true' Salafi manhaj in the Muslim majority lands. As explained above, in the case of Philips these authorities are associated with the major Saudi Arabian scholars such as Bin Baz, Al-Albani, and Al-Uthaymin.

Author Contributions: A.D.: Conceptualization, writing and editing; G.R.: background research and writing.

Funding: This research received no external funding.

Conflicts of Interest: The authors declare no conflict of interest.

\section{References}

'Atiyyah, 'Izzat 'Ali. n.d. Al-Bid'ah, 2nd ed. Beirut: Daar al-Kitaab al-'Arabee.

Abdul-Raof, Hussein. 2010. Schools of Qur'ānic Exegesis Genesis and Development. London: Routledge.

Abdul-Wahid, Abu Khadeejah. 2002. Available online: https://www.abukhadeejah.com/bilal-philips-the-deceitfuldefender-of-ahlul-bidah/ (accessed on 4 June 2019).

Ahmed, Rashid. 1997. 'Qur'ānic Exegesis and the Classical Tafsīr'. In Kur'an u Savremenon Dobu, (Qur'ān in the Contemporary Context). Edited by E. Karic. Sarajevo: Bosanski Kulturni Centar, El-Kalem, pp. 113-79.

Al-Albanee, Nasir. 2003. The Principals of Salafee Methodology: An Islamic Manual for Reform. Toronto: T.R.O.I.D. Azami, Mustafa. 2003. Studies in Hadith Methodology and Literature. Selangor: Islamic Book Trust.

Brown, Daniel. 1996. Rethinking Tradition in Modern Islamic Thought. Cambridge: Cambridge University Press. Brown, Jonathon. 2009. Hadith: Muhammad's Legacy in the Medieval and Modern World. Oxford: Oneworld.

Diamant, Jefrey. 2016. Engagement and Resistance: African Americans, Saudi Arabia and Islamic Transnationalisms, 1975 to 2000. Ph.D. Thesis, The Graduate Center, City University of New York, New York, NY, USA. 
Duderija, Adis. 2009. The evolution in the canonical Sunni Hadith body of literature and the concept of an authentic hadith during the formative period of Islamic thought as based on recent Western scholarship. Arab Law Quarterly 23: 1-27. [CrossRef]

Duderija, Adis. 2011. Constructing a Religiously Ideal 'Believer' and 'Woman' in Islam: Neo-traditional Salafi and Progressive Muslim Methods of Interpretation. New York: Palgrave.

Duderija, Adis. 2012. The Evolution in the concept of Sunnah during the first four generations of Muslims in relation to the development of the concept of an authentic hadith as based on recent western scholarship. Arab Law Quarterly 26: 393-47. [CrossRef]

Duderija, Adis. 2015. The Sunna and its Status in Islamic law: The Search for an Authentic Hadith. New York: Palgrave. Duderija, Adis, and Halim Rane. 2019. Islam and Muslims in the West: Major Issues and Debates. New York: Palgrave. Dutton, Yasin. 2003. The Origins of Islamic Law-The Qur' an, the Muwatta and Madinian' Amal. New York: Routledge.

Ghamidi, Javed. n.d. Islam: A Comprehensive Introduction. Translated by Shehzad Saleem. Lahore: Al-Mawrid A Foundation for Islamic Research and Education, Available online: http://www.al-mawrid.org/pages/ download_books.php (accessed on 4 June 2019).

Goldziher, Ignaz. 1952. Die Richtungen der islamischen Koranauslegung. Leiden: Brill.

Hallaq, Wael. 1999. The Authenticity of Prophetic Hadīth: A Pseudo-Problem Author. Studia Islamica 89: 75-90. [CrossRef]

Hallaq, Wael. 2001. Authority, Continuity, and Change in Islamic Law. Cambridge: Cambridge University Press.

Hallaq, Wael. 2005. The Origins and Evolution of Islamic Law. Cambridge: Cambridge University Press.

Hamid, Sadek. 2016. Sufis, Salafis and Islamists: The Contested Ground of British Islamic Activism. London: I.B. Tauris.

Hansu, Huseyin. 2009. Notes on the Term Mutawātir and its Reception in Hadith Criticism. Islamic Law and Culture 16: 383-408. [CrossRef]

Hansu, Husein. 2019. Theology. In Wiley Encyclopedia of Hadith. Edited by Daniel Brown. Hoboken: Wiley.

Ibn al-Ṣalāh. 2006. An Introduction to the Science of the Hadith, 1st ed. Translated by Eerik Dickinson. Reading: Garnet Publishing Limited.

Ibn Hazm, A. 1987. Al Kāmal fi usūl al-ahkām. Edited by Ahmad Shākir. Cairo: Mabaat al-Imām, vol. 1.

Ibn Manzur, Muhammad. 1956. Lisan al-Arab. Beirut: Dar al Fikr, vol. 15.

Jackson, Sherman. 2006. Literalism, Empiricism, and Induction. Michigen State Law Review 6: 1469-86.

Kamali, Hashim. 2002. Hadīth Methodology-Authenticity, Compilation, Classification and Criticism of Hadīth. Kuala Lumpur: Ilmiah Publishers.

Leemhius, Fred. 1988. Origins and Early Development of tafsīr. In Approaches to the History of the Interpretation of the Qur'ān. Edited by Andrew Rippin. Oxford: Clarendon Press, pp. 13-31.

Maher, Shiraz. 2016. Salafi-Jihadism: The History of an Idea. Oxford: Oxford University Press.

Meijer, Roel, ed. 2009. Global Salafism: Islam's new Religious Movement. New York: Columbia University Press.

Melchert, Christopher. 1997. The Formation of the Sunni Schools of Law in the 9th-10th Centuries. Leiden: Brill.

Melchert, Christopher. 2019. Law. In Wiley Encyclopedia of Hadith. Edited by Daniel Brown. Hoboken: Wiley.

Meleagrou-Hitchens, Alexander. 2018. Salafism in America: History, Evolution, Radicalization, George Washington University. Available online: https:/extremism.gwu.edu/sites/g/files/zaxdzs2191/f/Salafism\% 20in\%20America.pdf (accessed on 21 April 2019).

Motzki, Harald. 2003. The Question of the Authenticity of Muslim Traditions Reconsidered: A Review Article, in ed. Herbert Berg. In Method and Theory in the Study of Islamic Origins. Leiden: Brill, pp. 211-58.

Mubarak, Hadia. 2018. Change through Continuity: A Case Study of Q. 4:34 in Ibn Āshūr's al-Tahrīr wa'l-tanwīr. Journal of Qur'ānic Studies 20: 1-27. [CrossRef]

Philips, Bilal. 1990. Evolution of Figh, 3rd ed. Riyadh: International Islamic Publishing House.

Philips, Bilal. 2007. Usool ul Haidth. Riyadh: International Islamic Publishing House.

Philips, Bilal. n.d. Usool ul Tafseer. Riyadh: International Islamic Publishing House.

Roald, Anne-Sofie. 2012. The conversion process in stages: new Muslims in the twenty-first century. Islam and Christian-Muslim Relations 23: 347-62. [CrossRef]

Rohe, Mattias. 2014. Shari'a in the Muslim Diaspora. In The Ashgate Research Companion to Islamic Law. Edited by Rudolph Peters and Peri Bearman. Farnham: Ashgate, pp. 261-76.

Sadeghi, Behnam. 2004. The Structure of Reasoning in Post-Formative Islamic Jurisprudence: Continuity and Change in Post-Formative Positive Law Princeton. Ph.D. Thesis, Princeton University, Princeton, NJ, USA. 
Saleh, Walid. 2010. Preliminary Remarks on the Historiography of tafsīr in Arabic: A History of the Book Approach. Journal of Qur'ānic Studies 12: 6-40. [CrossRef]

Wiktorowicz, Quintan. 2006. Anatomy of the Salafi Movement. Studies in Conflict \& Terrorism 29: 207-39.

Wymann-Landgraf, Umar F. Abd-Allah. 2013. Mālik and Medina: Islamic Legal Reasoning in the Formative Period. Leiden and Boston: Brill.

Zysow, Aaron. 1984. The Economy of Certainty: An Introduction to the Typology of Islamic Legal Theory. Ph.D. Dissertation, Harvard University, Cambridge, MA, USA.

(c) ( (C) 2019 by the authors. Licensee MDPI, Basel, Switzerland. This article is an open access article distributed under the terms and conditions of the Creative Commons Attribution (CC BY) license (http://creativecommons.org/licenses/by/4.0/). 